November 21, 1893.

\title{
Sir W. H. Flower, K.C.B., LL.D., F.R.S., President, in the Chair.
}

The Secretary read the following report on the additions to the Society's Menagerie during the month of October :-

The registered additions to the Society's Menagerie during the month of October were 121, of which 57 were by presentation, 27 by purchase, 3 by birth, and 34 were received on deposit. The number of departures during the same period, by death and removals, was 106 .

The most noticeable additions during the month were:-

1. An example of the Goliath Beetle (Goliathus druryi), one of the largest of known Coleoptera, obtained near Accra, Gold Coast, and presented Oct. 5th by F. W. Marshall, Esq.

2. An adult female and a young of the Manatee (Manatus americanus), captured in Manatee Bay, Jamaica, and most kindly sent home for the Society's Collection by Sir Henry A. Blake, K.C.M.G. Unfortunately they reached the Gardens in a very exhausted condition, and died soon after their arrival.

Mr. Sclater exhibited a mounted specimen of an African Monkey (Cercopithecus albigularis) irom the Leyden Museum, and made the following remarks :-

Dr. Jentink has kindly sent to me from the Leyden Museum for comparison a West-African example of Cercopithecus albigularis, which I now exhibit. It was obtained by $\mathrm{Pel}$ on the Gold Coast, and therefore there can be no doubt as to its locality In my paper on the Monkeys of this genus, P. Z.S. 1893, p. 251, I commented upon the strange fact that this Monkey, which we commonly receive from Mozambique and various ports in East Africa, should also occur in West Africa, and suggested that specimens from the two countries should be compared. I have placed the present specimen side by side with the original type of Sykes (described P. Z. S. 1831, p. 106), now in the British Museum, and must admit that I can find no grounds for specific distinction. Sykes's specimen was originally living in the Society's Gardens, and its locality (given by Sykes as Madagascar) is absolutely uncertain; but of two East-African specimens obtained on the Rufiji River opposite Zanzibar, $8^{\circ} \mathrm{S}$. lat., by Capt. Wharton, R.N., F.R.S., and now in the British Museum, one agrees very well with the present specimen, though, as a general rule, East-African specimens (of which we have two now living in the Gardens) have a strong rufous tinge round the anus under the tail, which is not apparent in the present example. On the whole, however, I am not at present prepared to say that East and West African specimens of this Monkey can be properly distinguished. 
An extract was read from a letter addressed to the Secretary by Mr. J. S. Mackay, dated Dunbar House, Kullu, Punjaub, 10th June, 1893, relating to a young Snow-Leopard, then about one year old, which had been sent to Mrs. Mackay as a present from Thakur Debi Chand, of Gundla, in Lahaul, when quite small. Mr. Mackay wrote:- "The animal is well over six feet now. He is kept tied to a thin long cord during the day on the tenniscourt in the shade, where he gambols and plays with the dogs. At night he is let loose inside the house and sleeps on my wife's bed. I have never known or heard of anyone exercising such a peculiar fascination over any animal as my wife does over this Snow-Leopard. He follows her about like a dog, and if he misses her a moment he simply screams for her."

Several photographs representing this animal were exhibited.

Mr. W. B. Tegetmeier, F.Z.S., exhibited some hybrid Pheasants supposed to be crosses between the Common Pheasant (Phasianus colchicus) and the Gold Pheasant (Thaumalea picta), and between the first-named bird and the Silver Pheasant (Nycthemerus argentatus).

The following papers were read :-

\section{On the Spiders of the Family Attida of the Island of} St. Vincent. By G. W. and E. G. Рескнaм. ${ }^{1}$

[Received October 24, 1893.]

$$
\text { (Plates LXI. \& LXII.) }
$$

The Spiders of the family Attidæ described in the following paper were collected on the Island of St. Vincent by $\mathbf{M r}$. Herbert H. Smith, the collector sent out by Mr. F. DuCane Godman to assist the Committee for the Exploration of the Fauna and Flora of the West Indian Islands, appointed by the British Association and by the Royal Society.

The Committee has agreed to place a full series of these Spiders in the British Museum.

We had expected to have made this collection the basis of a discussion of the relations of the Spiders of the West Indian Islands to those of the mainland, but the material in our hands is too scanty to warrant any important conclusions. We hope, before long, to receive enough material to make the discussion desirable.

In making the measurements we have used the metric system.

Synemosyna smithi, sp. nov. (Plate LXI. figs. 1-1 b.)

$\sigma$ and $ᄋ$. Length $4 \cdot 2$. Length of cephalothorax $1 \cdot 8$; width of cephalothorax 9 .

${ }^{1}$ Communicated by D. Sharp, F.R.S., F.Z.S., on behalf of the Oommittee for Investigating the Flora and Fauna of the West Indian Islands. 


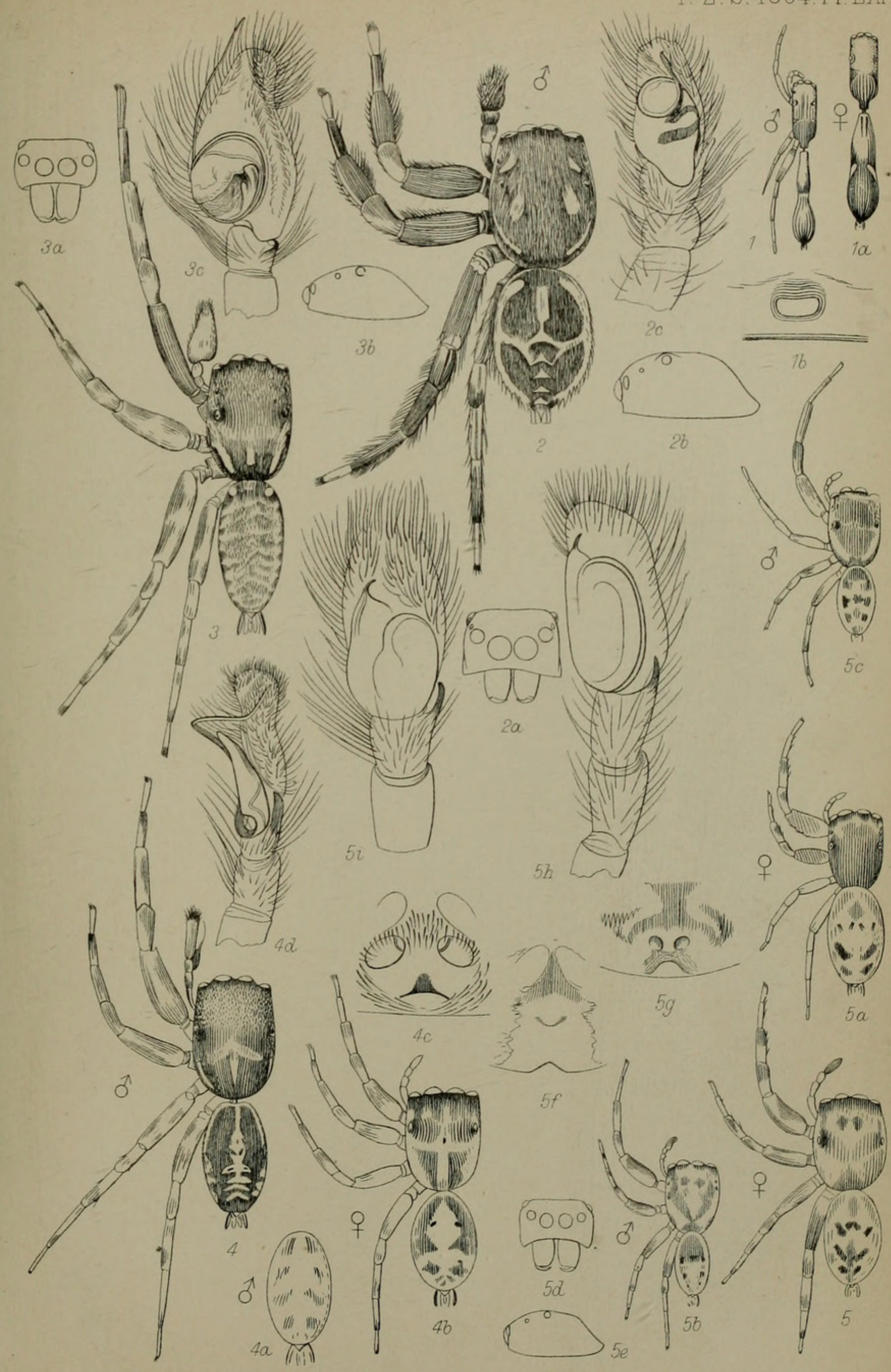

Eawin Wilson Cambriage 


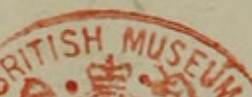

20.

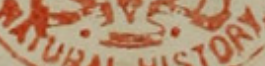




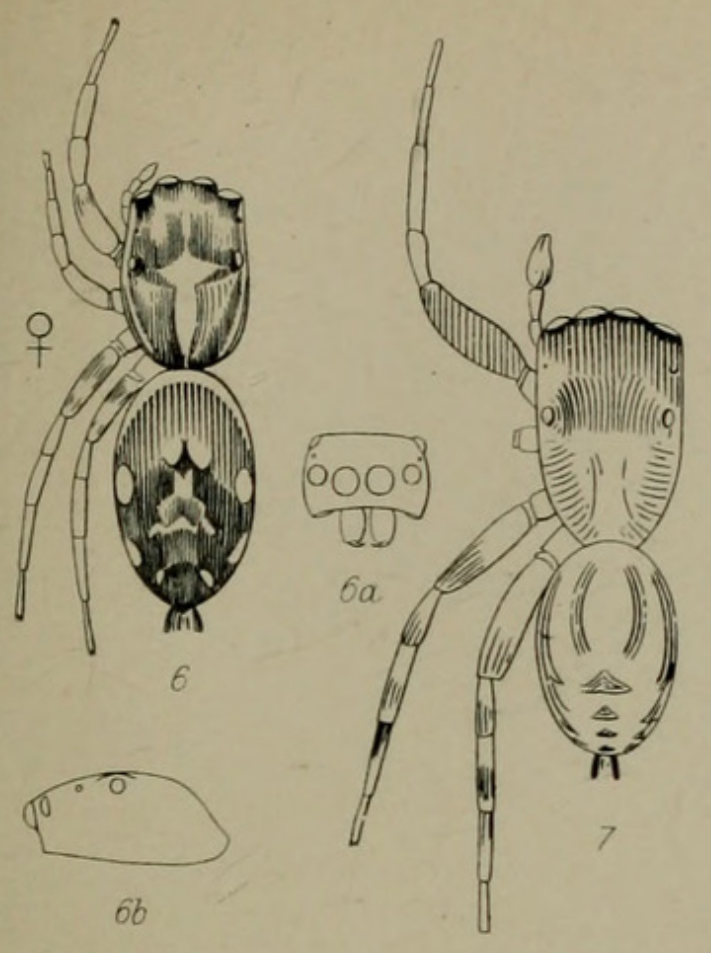

P. Z. S. 1894 . PI. LXII.

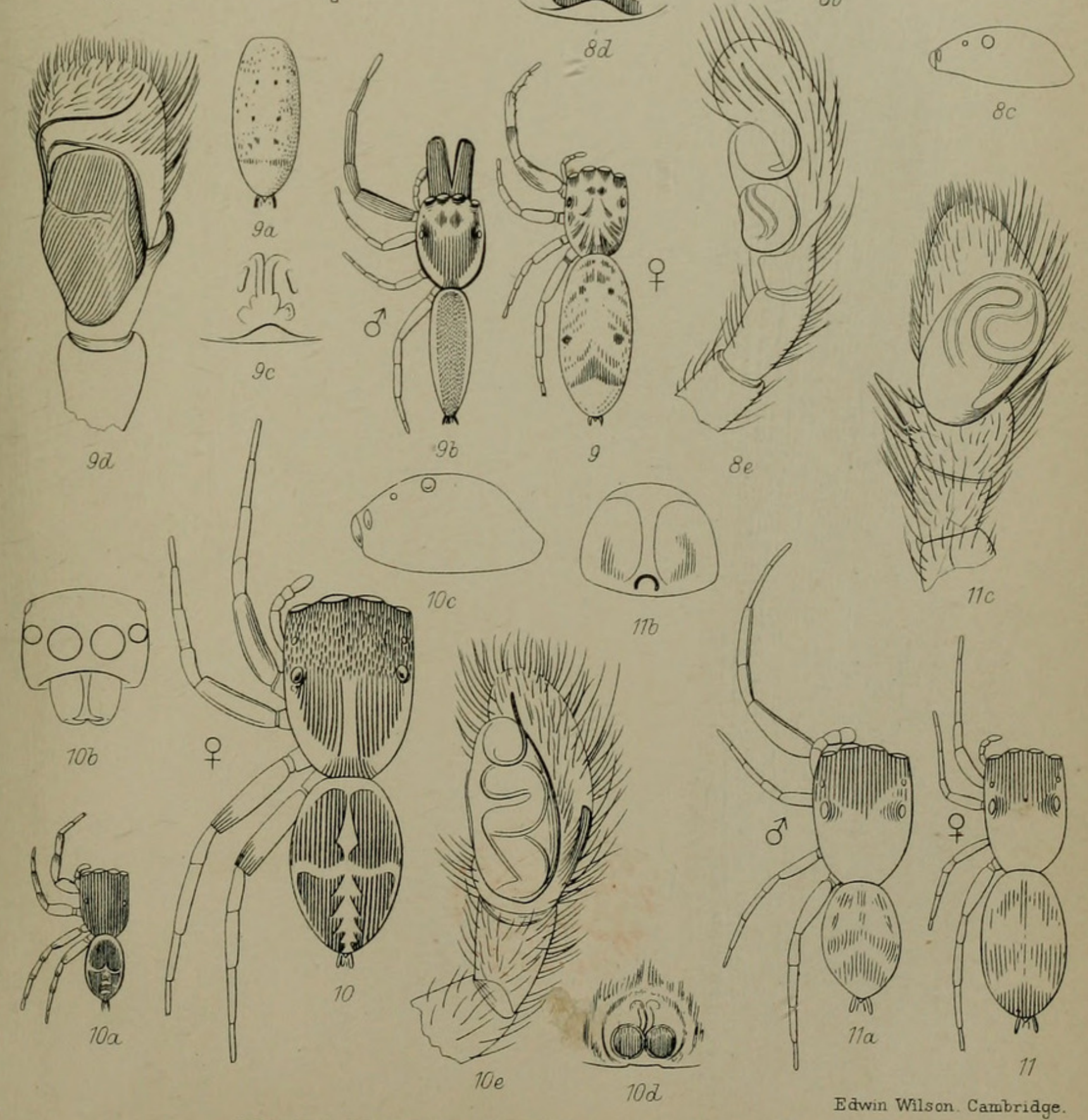

SPIDERS OF THE FAMILY ATTIDE FROM ST. VINCENT. 


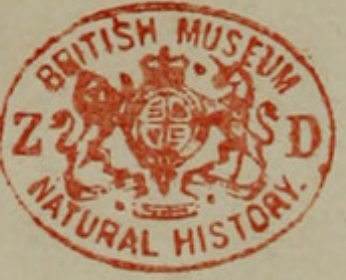


Legs, $\delta$ and $q, 4,3,1,2$. The femur of the fourth leg is enlarged, especially in the male.

The cephalothorax is narrow and long-twice as long as wide. The sides are nearly paratlel until the posterior quarter of the thoracic part, where the cephalothorax grows abruptly narrower. The cephalic part is on a higher plane than the thoracic and has its sides inclined inwards. The thoracic part is rounded in its anterior three-fourths, the posterior end, where it joins the abdomen, being flattened. There is a constriction at a little distance behind the dorsal eyes. The quadrangle of the eyes is nearly equally wide and long, is wider behind than in front, and occupies about one-third of the cephalothorax. The first row of eyes is strongly bent; the eyes are close together, the middle being twice and a half as large as the lateral. The second row is nearer the first than the third row. The dorsal eyes are larger than the lateral and form a row which is as wide as the cephalothorax at that place. The clypeus is narrow. The labium is wider than long. The sternum is long and narrow. The abdomen is very long and has a constriction in the middle; it is narrowest in front, tapering gradually toward the anterior end. The integument of the anterior part is slightly hardened above, on the sides, and below. The falces are moderately stout and long and are vertical.

The cephalic plate and the anterior thoracic part are yellow, with the eyes on black spots; there are some white hairs on the anterior pari; between the dorsal eyes are two fine dark lines; the rest of the upper surface is brown, darkening toward the posterior end, with a thin covering of white hairs, and having white bands around the two constrictions. The spinnerets are lightcoloured. The legs are white or light brown, excepting the femoral joints of the third and fourth pairs, which are rufous. The falces are reddish. The palpi, mouth-parts, and coxæ are white. The sternum and venter are yellowish, the venter being blotched with white.

\section{KeYSERLINGELLA MINUTA, sp. nov.}

․ Length 3. Length of cephalothorax $1 \cdot 3$; width of cephalothorax 8 .

Legs $4,3,1,2$, all slender.

The cephalothorax is rather short, with a slight constriction just behind the dorsal eyes. The cephalic part is flat, and is on a higher plane than the thoracic which is rounded, and falls quite steeply from the ridge behind the constriction. The sides are parallel. The abdomen is rounded, and is widest behind the middle and narrow at both ends. The clypeus is narrow. The quadrangle of the eyes is one-fourth wider than long, is wider behind than in front, and occupies about one-half of the cephalothorax. The first row is curved; the eyes are close together, the middle twice as large as the lateral. The second row is halfway between the first and the third. The dorsal eyes are larger than the lateral and are on the sides of the head. The sternum is-wide and is truncated 
in front. The maxillæ are twice as long as the labium. The labium is as wide as long.

The cephalothorax is dark rufous. In alcohol the abdomen is transversely banded with dark and pale rufous, with a wide dark band near the posterior end. When dried the anterior half is rufors with two transverse curved bands of white hairs; behind the second of these is a wide blackish band and between this and the spinnerets the colour is rufous. The palpi are pale. The legs are light 'rufous, the first pair unmarked, the second, third, and fourth with a black line running along the anterior face.

This spider is immature, but seems to belong to the genus Keyserlingella.

\section{Drnamius metallicus, sp. nov. (Plate LXI. figs. 2-2c.)}

o. Length $6 \cdot 8$. Length of cephalothorax 3 ; width of cephalothorax $2 \cdot 4$.

Legs $3,4,2,1$, nearly equal in length ; the first three pairs stouter than the fourth.

The cephalothorax is high and convex. The cephalic part is inclined forward and has the sides nearly vertical and parallel. The thoracic part has a nearly plane semicircular plate behind the dorsal eyes, from which it rounds downward on the sides and behind; it is very mnch narrower on the upper surface than below, the sides being concave. The quadrangle of the eyes is a little wider in front than behind, is one-fourth wider than long, and occupies not quite two-fifths of the cephalothorax. The eyes are all large. The first row is plainly curved with the eyes a little separated, the middle being less than twice as large as the lateral. The second row is halfway between the first and third rows. The dorsal eyes are a little smaller than the lateral and form a row which is not quite so wide as the cephalothorax, although it is as wide as the upper surface. The clypeus is two-thirds as high as the middle eyes of the first row. The falces are slightly retreating, short and not very stout. The sternum is wide and is truncated in front and behind. The maxillæ are short and are widely separated. The labium is fully as wide as long.

The whole appearance of this spider is big, black, and burly. The cephalothorax is ornamented with a pair of snow-white spots on the cephalic and another on the thoracic part, while the sides are encircled by a wide white band. On the black abdomen is a pattern in yellowish white with a tinge of red, consisting of an encircling band, a central, longitudinal, dorsal band, which in the posterior half is broken up into spots, and a curved transverse band on each side of the dorsum behind tne middle. The palpus has the femur and the proximal end of the patella covered with white hairs. The first two pairs of legs have the joints much enlarged and rounded ; in the third pair they are also enlarged but are lengthened out; the first, second, and third pairs have fringes of white hairs, and have all the joints, excepting the tarsi, iridescent, with brilliant violet reflections. Some of this iridescence is also seen on 
the upper surface of the cephalic part. The under surface is black.

Crbele, gen. nov.

The cephalothorax is rounded, convex and rather high, highest at the dorsal eyes; the cephalic part is plainly inclined. The quadrangle of the eyes is slightly wider in front than behind, is onefourth wider than long, and occupies two-fifths of the cephalothorax. The middle eyes of the first row project beyond the lateral and almost touch each other; the lateral are a little separated from the middle (more widely in vincenti than in obscura); they are unusually large, almost two-thirds as large as the middle eyes. The second row of eyes is nearer the third than the first row.

Cybele bears some resemblance to Amycus, but its general appearance is not so rounded, its sides are more nearly parallel, and the eyes of the first row are more nearly of a size, the middle ones of this row in Amycus being twice as large as the lateral. It also recalls Hasarius, but in this latter genus the eyes of the first row are much smaller and the thoracic part is flatter.

Crbele obscura, sp. nov. (Plate LXI. figs. 3-3c.)

${ }^{7}$. Length 7. Length of cephalothorax 3 ; width of cephalothorax 2.

․ Length 7 . Length of cephalothorax $2 \cdot 8$; width of cephalothorax 2 .

Legs, o $1,3,4,2$, o $3,4,1,2$, all nearly equally long. The first and second are a little the stoutest.

The cephalothorax has its sides nearly vertical in front, but in the thoracic part they are rounded out, more plainly than in vincenti; its widest point is a little behind the dorsal eyes. The thoracie part falls a very little in the first third of its length and then slants steeply. The first row of eyes is straight. The dorsal eyes are a little smaller than the lateral and are placed on the sides of the cephalothorax, which, however, is wider than this row below. The clypeus is half as high as the middle eyes of the first row. The falces in both sexes are vertical, parallel, and rather long and stout, with short fangs. The maxillæ are considerably longer than the labium and are widened at the extremities. The sternum is not much longer than wide, but is not so nearly round as in vincenti.

In colour and marking $C$. obscura is a good deal like vincenti. The cephalothorax is bright red, with a white band on each side and a third in the central thoracic region. The abdomen is covered with white and red hairs, giving it a tawny look; the anterior end is black and has two pairs of white bars, one above the other, and a bunch of black hairs projecting toward the cephalothorax. A line of fine white chevrons formed of hairs is faintly visible down the central line of the dorsum. The legs are brown, mottled and barred with red, white, and black. The tarsus and proximal end of the metatarsus of the first are not pale as in vincenti, and there is

Proc. Zoou. Soc.-1893, No. XLVII. 
no fringe of hairs on the underside. The spinnerets are long and pale, the outer ones having a dark line along the external side.

A common species.

The two species of Cybele may be distinguished from each other by the following points:-In $\dot{C}$. vincenti the thoracic part slants steeply from the dorsal eyes, while in $C$. obscura it falls gradually at first; in $C$. vincenti the falces of the male are oblique and diverging, in C. obscura vertical and parallel ; and in C. vincenti the palpus of the male has the tarsus twice as long as the tibia and not much longer than wide, while in $C$. obscura it is three times as long as the tibia and twice as long as wide, projecting for some distance beyond the bulb.

\section{Crbele vincenat, sp. nov. (Plate LXI. figs. $4-4 d$.)}

\section{thorax 2 .}

7 . Length 6 . Length of cephalothorax $2 \cdot 8$; width of cephalo-

․ . Length $6 \cdot 5$. Length of cephalothorax $2 \cdot 5$; width of cephalothorax $1 \cdot 8$.

Legs, of $1,4,3,2$, ㅇ 4, 3, 1,2. The first leg is stouter than the others and, in the male, is longer than the second by the metatarsus and tarsus.

The cephalothorax has its sides nearly vertical in front and slightly rounded out in the thoracic part; it is widest, as well as highest, at the dorsal eyes, and from this point it falls quite steeply, the slope being slightly rounded out. The first row of eyes is a little curved; the lateral eyes of this row are relatively a little smaller than those of obscura. The dorsal eyes are a little larger than the lateral and are placed on the sides of the cephalothorax, forming a row that is as wide as the cephalothorax at that place. The clypeus is one-fourth as high as the middle eyes of the first row. The patella and tibia of the male palpus are of the same length, and taken together are shorter than the tarsus, which is twice as long as wide; the palpal tube is very long. The falces of the male diverge widely and have long fangs; they are vertical and rather stout; those of the female are short, parallel, vertical, and rather stout, with short fangs. The maxillæ are not much longer than the labium. The sternum is almost round.

The markings vary considerably in different spiders of this species, and some are much darker coloured than others. The cephalothorax in the male is covered with brilliant red hair and has a snowy white band on each side and another in the central thoracic part. The abdomen is covered with a mixture of grey, red, and tawny hairs; around the anterior end is a curved white band, and from this a central, longitudinal, white band extends backward to about the middle of the dorsum. Sometimes a central band of white figures appears on the posterior half, with two dark rufous spots on each side. The clypeus bas a fringe of white hairs on the lower edge. The falces are brown. The legs are banded with lighter and darker brown, the first and second being somewhat darker than the third and fourth. The first leg has 
the tarsus and the proximal end of the metatarsus pale, and has fringes of black hair under the femur and the tibia. The spines are black.

In the female the whole spider is lighter coloured, the integument being brown, and there is less of the bright red than in the male. The ground-colour of the abdomen is a soft velvety reddish brown. The markings are like those of the male, and are equally variable. In both sexes the spinnerets are rather short, the external ones being covered with brown and the middle ones with white hairs.

A common species.

Dendryphantes octo-punctatus, sp. nov. (Plate LXI. figs. 5-5i.)

o. Length 5.5. Length of cephalothorax $2 \cdot 5$; width of cephalothorax 2 . Some males are considerably smaller, having a total length of about $3 \cdot 5$.

ㅇ. Length $4 \cdot 4$. Length of cephalothorax 2 ; width of cephalothorax $1 \cdot 8$.

Legs, of $1,4,2,3$; the first is stouter than the others and, especially in the larger variety, is much the longest, exceeding the second by the tarsus, metatarsus, and nearly all of the tibia ; the others are nearly equal. o $4,1,2,3$; the first is a little the stoutest.

The cephalothorax is scarcely longer than wide; the sides are curved, the widest point being behind the dorsal eyes. It is high, the highest point being at the dorsal eyes, the cephalic part falling slightly toward the first row of eyes, while the thoracic part rounds backward and downward quite abruptly in its first third and then falls still more steeply. The whole of the upper surface is rounded. The quadrangle of the eyes is one-third wider than long, is wider behind than in front, and occupies a little more than twofifths of the cephalothorax. The first row of eyes is a little curved; the middle eyes are separated slightly from each other and more widely from the lateral eyes. The lateral are a very little more than one-half as large as the middle eyes. The second row of eyes is nearer the first than the third row. The third row is plainly not so wide as the cephalothorax at that place. The clypeus is narrow. The falces of the male are stout, rather long, with long strong fangs, diverging and somewhat obliquely directed forward, so that they are sometimes visible from above; those of the female are rather stout and long, parallel, and vertical. The sternum is oval. The maxillæ are fully twice as long as the labium and are rounded. The labium is longer than wide.

In the male the integument is of a rich dark brown colour. The upper surface of both cephalothorax and abdomen seems to have been covered with yellow hairs or scales. There are two wide snow-white bands on the sides of the cephalothorax, and a curved white band around the anterior end and the sides of the abdomen. On the dorsum are eight dark spots on a light ground, 
four in a transverse row across the anterior part and two on each side, farther back. The two middle spots of the transverse band are frequently joined together. There are some red hairs around the eyes of the first row, and the front faces of the first legs; the palpi and the falces are all covered with snow-white rice-like scales, so that the spider presents a very showy appearance from in front. The legs are brown with a good many white scales, the first pair being darker coloured than the others.

The female has the integument of the cephalothorax dark brown, while that of the abdomen is commonly yellowish. The whole surface is covered with white scale-like hairs, excepting that on the abdomen there are eight black spots, four in a transverse row across the middle of the dorsum and two on each side, farther back. The legs are yellowish. The clypeus is covered with rather long white hairs, which hang down a little way over the falces.

The general appearance of this species is much like that of Dendryphantes capitatus, Hentz. It seems to be very common in St. Vincent.

Hasarius paykulli, Aud. in Sav. Descr. de l'Egypte, $2^{e}$ édit. xxii. p. 172.

A cosmopolitan species.

Cyrene, gen. nov.

The cephalothorax is only moderately high; from its highest point, at the dorsal eyes, it falls forward to the first row of eyes and backward for about two-thirds of the length of the thoracic part, the forward inclination being a little more pronounced than the backward. The final fall to the posterior border is steep. The sides are nearly vertical and parallel in the cephalic part, but are a good deal rounded out in the thoracic, the widest point being considerably behind the dorsal eyes. The quadrangle of the eyes is equally wide in front and behind, is barely one-fourth widèr than long, and occupies two-fifths of the cephalothorax. The first row of eyes is straight, the middle eyes being about twice as large as the lateral and close together, while the lateral are a little separated from them. The second row is halfway between the first and the third row. The dorsal eyes are about as large as the lateral, and form a row which is nearly as wide as the cephalothorax at that place.

This genus is close to Mavia, but the cephalothorax has a more rectangular appearance, the lower edge being almost straight.

Crrene decorata, sp. nov. (Plate LXII. figs. 6-6 b.)

ㅇ. Length $5 \cdot 8$. Length of cephalothorax $2 \cdot 2$; width of cephalothorax $1 \cdot 4$.

Legs $4,3,1,2$, nearly equally stout, the femoral joints of the first and second being a little thickened.

The clypeus is one-fourth as high as the middle eyes of the first row. The falces are moderately long and stout, vertical and 
parallel. The sternum is narrowed and truncated in front and rounded behind. The maxillø are twice as long as the labium, which is short, wide, and squarely truncated. The abdomen is widest in the middle.

The cephalic part is bright red. There is a wide white band on each side and a central white band on the thorax ; the rest of the thoracic part is darker than the cephalic, but is decidedly reddish. The abdomen has a black curved band around the anterior end, and above this a snow-white band. The upper surface is bright red, with two longitudinal black bands from the middle of the dorsum to the spinnerets, between which the surface is bronzed, and a number of snow-white spots which form a handsome and effective pattern (see drawing). Two of these are in the middle of the abdomen just in front of the bronze region; two more appear at the edge of the bronze region on each side; and two larger spots, also snow-white, are found on each side of the abdomen in the red region.

The middle spinnerets are pale, the external ones black. The legs are light coloured, irregularly dotted with black. The clypeus is covered with long white hairs. The falces and mouth-parts are dark reddish brown. The sternum is light brown. The venter is covered with white hairs and is dotted with black.

A single specimen.

We have examples of this species in the Smith collection from Santarem, the Brazilian variety being larger. It has a general resemblance to Euophrys coronigera of C. Koch.

\section{Euophrys (?) PULCHella, sp. nov. (Plate LXII. figs. 7, 7 a.)}

${ }^{*}$. Length 3 . Length of cephalothorax $1 \cdot 5$; width of cephalothorax 1 .

Legs $4,3,1,2$.

The cephalothorax is high and looks rather long and heavy compared to the abdomen. The sides are nearly parallel and vertical, but widen out a little at the posterior end. The highest point is at the dorsal eyes. The cephalic part is gently inclined, and the anterior two-thirds of the thoracic part falls a little more abruptly. The final slope of the thoracic part to the margin is steep. The four anterior eyes are close together in a curved row ; the lateral are two-thirds as large as the middle eyes. The second row is a little nearer the third than the first row. The third row is as wide as the cephalothorax at that place, the eyes being nearly as large as the lateral eyes of the first row. The clypeus is narrow. The falces are short, vertical, and parallel. The sternum is wide, slightly rounded in front and pointed behind. The maxillæ are widely separated and are truncated at the extremities. The labium is very small and is as wide as long.

Our single specimen of this species is so badly rubbed that the colour can only be guessed at. The cephalothorax is dark brown with a black line around the lower margin, and seems to have been pretty well covered with white hairs. The abdomen is lighter 
brown, with a pale herring-bone stripe down the middle of the dorsum and a good many white hairs on the sides. The legs and palpi are light brown, the legs having some dark rings. The falces are dark brown. The under surface is light brown.

This spider is immature. It is not a very good Euophrys, but as it is near that genus we put it there provisionally.

\section{Crdonia, gen. nov.}

The cephalothorax is low and is almost flat above. The cephalic part is very slightly inclined, and the thoracic part falls scarcely at all in the anterior half and then slopes abruptly to the margin. The sides are narrowest in front; they widen a little just behind the dorsal eyes and then contract gradually as they pass backward; in the cephalic part they slant inward, but in the thoracic part they are gently rounded. The quadrangle of the eyes is wider behind than in front, is one-fifth wider than long, and occupies one-half of the cephalothorax. The four anterior eyes are placed close together in a straight row, the middle being nearly twice as large as the lateral. The second row is nearer the first than the third row. The dorsal eyes are fully as large as the lateral eyes of the first row and are placed on the margin of the cephalothorax. The labium is longer than wide.

Cydonia is somewhat like Epiblemum, but differs from that genus in that the quadrangle of the eyes is wider behind than in front and occupies one half of the cephalothorax.

Cydonia luteola, sp. nov. (Plate LXII. figs. 8-8e.)

ot Length 3 . Length of cephalothorax 1.5 ; width of cephalothorax 1 .

ㅇ. Length 3.8 . Length of cephalothorax 1.5 ; width of cephalothorax 1.

Legs, of o, 4, 1, 3,2. The first pair is much the stoutest in both sexes, all the joints excepting the metatarsus and tarsus being thickened.

The clypeus is narrow. The falces are only moderately long and stout; in the male they diverge and are directed obliquely forward, the fang being as long as the falx ; in the female they are vertical and parallel with the fang, short. The sternum is oblong. The maxillæ are rounded and are less than twice as long as the labium. The abdomen is long in proportion to the cephalothorax and is about twice as long as wide.

The cephalothorax is black in the cephalic region, shading into rufous behind; the upper surface is covered with bright yellow hairs and there is a band of white hairs on each side. The abdomen is light brown covered with silvery down, and on each side is a longitudinal white band. Touching these lateral bands are two pairs of short white bands or spots, the first pair near the middle and the second near the spinnerets. The first leg has the 
femur, tibia, and a ring at the distal end of the metatarsus rufous, the remainder being pale; in the female the rufous is not so dark as in the male. The other legs are pale. The palpus of the male is black covered with white hairs, excepting the tarsus, which is pale. The palpus of the female is all pale. In both sexes the falces are dark rufous and glossy.

Marptusa melanognatha, H. Lucas, Webb and Berthelot's Hist. Nat. des Iles Canaries, tome ii. p. 29, pl. vii. fig. 4.

A cosmopolitan species.

ANoKa, gen. nov.

The cephalothorax is not high and is not much longer than wide; the sides widen out gradually from the lateral eyes to their widest point, which is behind the dorsal eyes ; they slant outward more widely in the thoracic than in the cephalic part. The cephalic part is inclined forward; the thoracic is level for twothirds of its length and then falls rather steeply. The quadrangle of the eyes is one-third wider than long, is a little wider behind than in front, and occupies two-fifths of the cephalothorax. The first row of eyes is straight, with the middle eyes subtouching and less than twice as large as the lateral, which are a little separated from them. The second row is about halfway between the first and third rows. The third row is narrower than the cephalothorax at that place, the eyes being a little farther from each other than from the lateral borders. Abdomen long and slender.

We have species of Anoka from various parts of the United States, from Jamaica, St. Vincent, Barbados, and New Granada. They all resemble each other very strongly, even the patterns and colours being often reproduced. The relative length of the legs is $1,4,2,3$ or $1,4,3,2$ in both sexes. The males are more slender than the females and have the first legs much longer and stouter than the others and, usually, dark coloured, the other legs being pale. The males also, in all the species except $A$. mitrata and an unpublished species from Jamaica, have the falces long and horizontal; in the Jamaica species they are oblique, and mitrata has the falces vertical and the first legs pale. The mouth-parts are always dark coloured.

Anoka is related to Icius and Menemerus, but in Icius the eyes of the first row are larger, the cephalothorax has the sides more nearly parallel and the thoracic part differently shaped (see drawing), and the abdomen is not so long and slender. In Menemerus the sides dilate suddenly behind the third row of eyes, the thoracic part slants more steeply from the dorsal eyes and is wider behind, although not so wide as in Icius, and the cephalic part is more steeply inclined.

ANoka verNaLIS, sp. nov. (Plate LXII. figs. 9-9 d.)

o. Length 4.8 . Length of cephalothorax $1 \cdot 8$; width of cephalothorax $1 \cdot 5$. 
․ Length 5. Length of cephalothorax 2.1. Width of cephalothorax $1 \cdot 8$.

Legs, o o , 1, 4, 3, 2; first pair much the stoutest and longest, especially in the male.

The falces of the male are long, longer in some specimens than in others, and horizontal. Their inner edges are parallel for about one-half their length and then diverge; at this point is a tooth, which points forward and crosses the one on the opposite falx. The fang is long and slender and is slightly curved at the extremity. Those of the female are vertical, parallel, and moderately long and stout. The sternum is rather long, and is widest in the middle. The maxillæ are nearly twice as long as the labium. The labium is longer than wide.

The colour of the male is bronze-brown. A snow-white band on each side extends throughout the whole length of the cephalothorax and abdomen, the cephalothorax having a dark line around the lower margin. The eyes of the first row are surrounded by white hairs. The falces are bronze, slightly rugose above, with a band of white hairs along the outer side of each. The fangs are black. The first legs are bronze above and blackish below, and are thinly covered with white hairs. The other legs are light yellowish brown.

The female has the cephalothorax and abdomen thickly covered with a mixture of white, red, and yellow hairs. On the anterior part of the abdomen are two pairs of black dots, and across the posterior part, halfway between the middle point and the spinnerets, is a transverse black band. The legs are yellowish brown, the first pair being the darkest and having some short white hairs.

Prostheclina PygmaA, sp. nov. (Plate LXII. figs. 10-10e.)

o. Length 3. Length of cephalothorax $1 \cdot 5$; width of cephalothorax 1 .

ㅇ. Length $3 \cdot 7$. Length of cephalothorax $1 \cdot 7$; width of cephalothorax $1 \cdot 3$.

Legs, o $1,4,3,2$, ㅇ $3,4,1,2$; almost equally stout in both sexes.

The cephalothorax is high, the highest point being at the dorsal eyes; it is widest in front. The cephalic part is strongly inclined forward and projects over the lower margin, the sides and clypeus slanting inward. The thoracic part falls a little in the anterior two-thirds and then drops abruptly behind; the lateral slopes of this part are slightly rounded out. The quadrangle of the eyes is one-fourth wider than long, is plainly wider in front than behind, and occupies a little less than one-half of the cephalothorax. The four anterior eyes are close together and form a curved row; they are not very unequal in size, the lateral being about two-thirds as large as the middle eyes. The front face of the cephalothorax is so inclined that the eyes of this row look downward. The second row is plainly nearer the third than the first row, and the eyes are placed on the sides of the cephalothorax. 
The sternum is large and almost round. The maxillæ are short and broad. The labium is very small and about as wide as long. The clypeus is about one-fourth as high as the middle eyes of the first row. The falces are moderately long and stout; they are parallel and are inclined backward.

This spider is black, ornamented with a handsome pattern in white. The cephalothorax of the male has white bands encircling the sides, a white band across the cephalothorax above the first row of eyes, another passing down the middle of the thorax, and a shorter curved band on each side, which passes up from the lateral band between the eyes of the second and third rows, and then divides, joining the band across the cephalic part in front and the thoracic band behind. The abdomen has also a number of white bands. There is a central one down the middle; a curved band on each side which joins the central one before and behind; and a transverse bar a little behind the middle, joining the central to the lateral bands, and thus dividing the dorsal surface of the abdomen into two posterior and two larger anterior black spots, surrounded by white. The legs are of rather a bright rufous. In the male the anterior faces of the tibial joints of the third pair are covered with black hairs. In the female all the femoral joints are blackish. The tibia of the palpus is covered with snow-white hairs, and there is a fringe of white hairs on the edge of the clypeus. The white band above the first row of eyes is also visible from the front, so that the face view is very striking. In the female the general colouring is like that of the male, excepting that the white band above the anterior row of eyes is lacking.

Neon pompatus, sp. nov. (Plate LXII. figs. 11-11 c.)

o. Length $2 \cdot 5$. Length of cephalothorax $1 \cdot 2$; width of cephalothorax 1 .

․ Length $3 \cdot 2$. Length of cephalothorax $1 \cdot 2$; width of cephalothorax $\cdot 8$.

Legs, of 1, 4, 3, 2, ㅇ 4, 1, 3, 2; first pair a little the stoutest.

The cephalothorax is high, with the cephalic part inclined forward, and the thorax falling but slightly for a very short distance behind the dorsal eyes, and then more steeply, in a long slant, to the posterior border. The quadrangle of the eyes is about equally wide in front and behind, is one-fifth wider than long, and occupies a little more than one-half of the cephalothorax. The first row of eyes is straight; the eyes are all close together and are all small, the middle being less than twice as large as the lateral. The dorsal eyes are larger than the lateral, and form a row which is as wide as the cephalothorax at that place. The eyes of the second row are nearer the dorsal than the lateral eyes. The clypeus is very narrow. The falces are short, weak, parallel and vertical. The labium is as wide as long. The sternum is nearly round. In the female the abdomen looks wide and heavy when compared with the cephalothorax. 
The cephalothorax is black in the cephalic and brown in the thoracic fart, sometimes thinly covered with white hairs, and having some white and rosy hairs around the eyes of the first row; around the lower border is a black line and above this is a white line. The cephalothorax seems to have been entirely covered with very brilliant iridescent scales of a rosy-golden colour, and has two white spots on each side and one just in front of the spinnerets. The legs are medium brown, the first one, in the male, being blackish on the under surface.

This is a very small spider. It does not altogether agree with the genus Neon, the dorsal eyes being not very large, and the slope from the dorsal eyes being less abrupt.

Lyssomanes, sp. inc.

This is an immature specimen of the subgenus Jelskia. The species cannot be determined. The relative length of the legs is $1,2,3,4$; the first leg is long and spined. The colour was probably grass-green in life, but has faded to pale yellow.

\section{EXPLANATION OF THE PLATES.}

\section{Plate LXI.}

Fig. 1. Synemosyna smithi (p. 692), dorsal view of male; $1 a$, dorsal view of female; $1 b$, epigynum.

2. Dynamius metallicus (p. 694), dorsal view of male; $2 a$, face and falces; $2 b$, side view of cephalothorax; $2 c$, palpus.

3. Cybele obscura (p. 695), dorsal view of male; $3 a$, face and falces; $3 b$, side view of cephalothorax; $3 c$, palpus.

4. Cybele vincenti (p. 696), dorsal view of male; $4 a$, abdomen of a variety of the male; $4 b$, dorsal view of young female; $4 c$, epigynum; $4 d$, palpus.

5. Dendryphantes octo-punctatus (p. 697), dorsal view of female; 5 a, dorsal view of variety of female; $5 b$, dorsal view of male; $5 c$, dorsal view of variety of male; $5 d$, face and falces ; $5 e$, side view of cephalothorax; $5 f$, epigynum ; $5 g$, variety of epigynum; $5 h$, palpus; $5 i$, variety of palpus.

\section{Plate LXII.}

Fig. 6. Cyrene decorata (p. 698), dorsal view of female; $6 a$, face and falces; $6 b$, side view of cephalothorax.

7. Euophrys (?) pulchella (p. 699), dorsal view of male; $7 a$, palpus.

8. Cydonia luteola (p. 700), dorsal view of female; $8 a$, dorsal view of male; $8 b$, face; $8 c$, side view of cephalothorax; $8 d$, epigynum; $8 e$, palpus.

9. Anoka vernalis (p. 701), dorsal view of female; $9 a$, abdomen of variety of female; $9 b$, dorsal view of male; $9 c$, epigynum ; $9 d$, palpus.

10. Prostheclina pygmea (p. 702), dorsal view of female; $10 a$, dorsal view of young male; $10 \mathrm{~b}$, face and falces; $10 \mathrm{c}$, side view of cephalothorax ; $10 d$, epigynum; $10 e$, palpus.

11. Neon pompatus (p. 703), dorsal view of female; $11 a$, dorsal view of male; $11 b$, epigynum; $11 c$, palpus. 
2. A List of the Hemiptera-Heteroptera collected in the Island of St. Vincent by Mr. Herbert H. Smith; with Descriptions of New Genera and Species. By P. R. UHLER. ${ }^{1}$

[Received October 23, 1893.]

\section{A. List of Species of which specimens were obtained.}

Diolcus boscii, $\mathrm{Fab}$., ơ 우. (Uncoloured state.)

Sphyrocoris obliquus, Germ.

Symphylus deplanatus, H.-Schf.

Thyreocoris pulicarius, Germ.

Pangæus serripes, Hope.

Pangæus sp.

Amnestus subferrugineus, Hope.

Mormidea ypsilon (Linn.). Small var.

Euschistus bifibulus, Pal. Beauv.

Proxys victor, Fab.

Arvelius albopunctatus, De Geer.

Piezodorus guildingii, Westw.

Thyanta perditor, Fab.

casta, Stal.

Nezara viridula, Linn.

Edersa cornuta, Burm.

Spartocera diffusa, Say.

fusea, Thunb.

Anasa bellator, $F a b$.

- scorbutica, $\mathrm{Fab}$.

Acanthocerus tuberculatus, H.-Schf.

Hyalymenus longispinus, Stål.

Alydus pallescens, Stål.

Leptocorisa filiformis, Fab.

Leptoglossus balteatus, Limn.

Zicea tæniola, Dallas.

Catorhintha mendica, Stål, var.

Darmistidus maculatus, sp. nov.

Harmostes serratus, $\mathrm{Fab}$.

Corizus zidæ, Fab. (var. C. pictipes, Stål).

Ochrimnus collaris, Fab.

Oncopeltus cingulifer, Stal. fasciatus, Dallas. varicolor, Fab.

Myodocha unispinosa, Stål.

Pamera serripes, Fab.

Sphærobius gracilis, sp. nov.

Tomopelta munda, sp. nov.
Clerada apicicornis, Signoret. (Very large.)

Pachygrontha longiceps, Stål. (Large Q.)

Gonatas divergens, Dist.

Blissus leucopterus, Say. (One dwarf.)

Ptochiomerus dohrnii, Guérin.

Ozophora pallescens (Dist.).

sp. inc.

— burmeisteri, Guérin.

Geocoris lividipennis, Stål (var.).

Pamera bilobata, Say.

- vincta, Say.

Nysius providus, sp. nov. (vars.).

Oymus virescens, $F a b$.

Ninus notabilis, Dist.

Ptochiomera oblonga (Stål).

- sp. inc. (soiled).

Bathydema socia, sp. nov.

Plinthisus sp. inc. (damaged).

Ischnorhynchus championi, Dist.

Protacanthus decorus, sp. nov.

Dysdercus annuliger, Uhler.

Trigonotylus pulcher, Reuter.

Megacolum rubrinerve, Dist.

Lygus prasinus, Reuter.

- obtusus, sp. nov.

Fulvius albomaculatus, Dist.

Melinna minuta, sp. nov.

sp. inc.

Engytatus geniculatus, Reuter.

Collaria explicata, Uhler.

Phytocoris eximius; Reuter.

Mala decoloris, Dist. (damaged).

Cyrtocapsus caligineus, Stål.

Eccritotarsus atratus, Dist.

Pycnoderes quadrimaculatus, Guérin.

Cylloceps pellicia, Uhler.

Macrolophus separatus, Uhler.

1 [Communicated by Dr. D. Sharp, F.R.S., on behalf of the W. India Islands Committee.

N.B.- The specimens dealt with in this memoir were collected by $\mathrm{Mr}$. H. H. Smith, who was sent to the islands for the assistance of the Committee by F. D. Godman, Esq., F.R.S. Prof. Uhler is at present engaged in working out the larger collection formed by Mr. H. H. Smith and Mr. Summers in the neighbouring island of Grenada, and reserves remarks on the distribution of the species until the larger work is complete.-D. S.] 


\section{List of Species (continued).}

Fundanius rubens, sp. nov.

Pœeiloscytus obscurus, sp. nov.

Agalliastes simplex, Uhler.

Corythuca sp.? Allied to C.gossypii, Fab.

Typonotus planaris, Uhler, sp. nov.

Teleonemia sacchari, $\mathrm{Fab}$.

Phymata annulata, Uhler.

Coriscus capsiformis, Reuter.

roripes, Reuter.

Saica recurvata, Fab.

Stenopoda culiciformis, $\mathrm{Fab}$.

Narvesus carolinensis, Stål.

Henicocephalus flavicollis, Reuter.

Emesa angulata, Uhler, sp. nov.

Luteva gundlachii, Guérin.

Westermannia tenerrima, Dohrn.

- sp.?, immature.

Cerascopus ? larva.
Emesopsis nubilus, Uhler, sp.nov.

Salda humilis, Say.

- humilis, var. Large size.

Pelogonus marginatus, Latr. Two varieties.

Limnometra marginata, Guérin.

Brachymetra albinervis, Amyot.

Microvelia pulchella, Westw. Unwinged.

— capitata, Guérin. Dark coloured form.

- marginata, Uhler. New sp.

Mesovelia bisignata, Uhler.

Rhagovelia obesa, Uhler.

- elegans, sp.nov.

Zaitha anura, H.-Schf.

Anisops elegans, Fieber.

- pallipes, Fabr. Immature.

Plea striola, Fieber.

There are also in the collection representatives of about 9 species of the family Anthocoridæ and of about 8 species of Ceratocombidæ.

B. Descriptions of New Genera and Species.

Fam. Co R EID A.

Sect. Alydina.

\section{DarMISTIDUS, gen. nov.}

Form shorter than usual, almost flat above, the basal division of pronotum less sloping than usual. Head large and long, fully as long and a little wider than the pronotum, much wider than deep, gradually narrowing behind the eyes; the ocelli large, placed behind the line of the eyes and wide apart, but not far from the eyes; the eyes globular, moderately prominent laterally; the tylus narrow and gently sloping, enlarged at tip and a little bent down towards the base of rostrum. Antennæ slender, short, the basal joint thick, short, and not extending much beyond the tip of tylus ; the second and third joints long, nearly equal, more slender than the others; the apical joint much thicker, scarcely as long as the third, contracted and a little bent at tip. Rostrum slender, reaching bețiveen the posterior coxæ ; the bucculæ slender, waved in front and not enclosing the base of the first joint, the first joint shorter than the throat. Pronotum trapeziform, almost as long as wide, with the disk convex each side of the deep longitudinal groove, the apex contracted by a narrow collum, which is followed behind by a transverse curved series of slender callosities; the lateral margins bluntly carinate, oblique and feebly sinuated; the posterior margin is callous each side, and has lamellar lobes between the callosities and the humeral tubercle. Scutellum long and narrow, with the submargin carinate to near the acute tip. Tip of corium short, a little blunt, and not protracted backwards as in Alydus and next related genera; membrane long, charged with numerous, chiefly simple 
and almost straight veins, the one next the outer apex forked. Posterior femora bent, stout, projecting about one-fourth of their length beyond the end of venter, armed beneath with series of short and longer teeth, which are set closer and arranged in a double series on the apical half.

\section{Darmistidus maculatus, sp. nov.}

Pale testaceous, shaded and flecked with fuscous. Closely related to Siachyocnemis, but with a longer head and less robust figure, and destitute of the pilous covering of the head and pronotum. Head obsoletely punctate, minutely pubescent, with the longitudinal middle line slender and faintly defined; the crown and the surface at the ocelli marked with fuscous; throat pale testaceous; antennæ pale fulvous, the basal joint darker ; rostrum piceous at tip and along the middle line. Pronotum either testaceous or pale fulvous, marked with dark brown dots, minutely, remotely pubescent, closely punctate and somewhat granulate, with the central line pale and the callosities dark brown; the humeral prominences and the posterior submargin usually brown, with the edge paler; the sternum pale and the pleural pieces darker and punctate. Legs sprinkled with reddish brown; the tibiæ pale testaceous, banded with a few dark brown, slender lines; tarsi with the last joint, nails, and tip of the long basal joint blackish. Scutellum remotely punctate, granulate, fuscous at base, and white on the apex and subapical carinate border. Hemelytra thin, translucent, greenish white, or pale fulvo-testaceous, with the veins interruptedly rufo-castaneous, and the thick end of the medial vein, apex of the clavus, and border at tips of corium piceous black; membrane whitish, with the veins minutely and faintly marked with rufous. Tergum with a broad black stripe along the middle, which grows narrower towards the tip; venter pale, smooth, minutely, transversely wrinkled, a little punctate on the middle and at base.

Length to tip of venter $6 \frac{1}{2}-7$ millim.; width of base of pronotum $1 \frac{3}{4}-2$ millim.

Four specimens, one without a head.

\section{Fam. B ERYTID 死.}

\section{Protacanthus, gen. nov.}

Form of Metacanthus, Fieb., with the same tumidly convex head and conically produced clypeus. Eyes subspherical, set laterally and below the line of the vertex; ocelli placed far behind the eyes on a collum-like distinct lobe. Antennæ long and slender, the basal joint longest, not quite so long as the posterior femur, but longer than the two following joints united, minutely clavate at tip; the second and third joints subequal, still more slender; the apical joint shorter than the third, slender, fusiform. Rostrum slender, reaching to the posterior coxæ, with the basal joint not quite so long as the head. Pronotum short and stout, scarcely 
wider anteriorly than the base of head, the anterior margin forming a collum, which is armed each side with an obliquely directed spine; posterior lobe wide and convex, carinate on the middle line, the posterior border deflexed, with the edge reflexed. Scutellum armed with a long, erect, curved spine. Corium long, impunctate, carried far along the border of the membrane, tender and translucent; veins of membrane few, long, curved, not connected by cross-veins. Legs long and slender, the middle and posterior femora a little thickened towards the tip. Abdomen long, a little shorter than the wing-covers, subcylindric, contracted at base, tapering from the middle to the tip.

\section{Protacanthus Decorus, sp. nov.}

Pale tawny yellow, with the head black and highly polished, the collum of the pronotum white, the spines pale testaceous, and the abdomen greenish testaceous, polished and impunctate. Antennæ yellowish, with the basal joints and tips of the following ones darker, the apical joint fuscous ; rostrum pale yellow, darker at tip. Pronotum coarsely punctate, with the surface a little tumid behind on each side of the middle line; pleuræ also punctate. Legs pale honey-yellow, a little darker on tips of femora, the tibiæ annulated with black. Wing-covers whitish, translucent, the membrane hyaline.

Length to tip of wing-covers 4 millim.; width of pronotum $\frac{3}{4}$ millim.

Two specimens of this interesting species were collected by Mr. H. H. Smith on low swampy land, in an open place, near sea at the south end of the island, September 27.

\section{Fam. LYG $\mathbb{A} I D$ E.}

Tomopelta, gen. nov.

Robust, oval, with both ends narrowed, opaque and pubescent above. Head short, set in as far as to the eyes, small, narrow, acutely triangular above; antennæ stout, about as long as the head, pronotum, and scutellum united, the basal joint longer than the head, the second joint a little longer than the third and subequal to the fourth, all conspicuously pubescent; throat flat; the rostrum reaching between the middle coxæ, basal joint as long as the throat. Pronotum distinctly bilobate, broad, the anterior lobe much wider than the head, longer than the posterior lobe, collarlike, one grade narrower and lower than the basal one, both arched, and with their lateral margin reflexed concurrently with the curve of each ; prosternum with an uneven longitudinal ridge on each side of the middle line; the pleural pieces coarsely punctate, polished. The anterior femora fusiform, compressed. Scutellum longer than wide, abruptly acute at tip. Hemelytra coarsely punctate, pubescent, dull, the costal margins almost straight and parallel, a little sinuated on the middle; the costal area wide and grooved; membrane with the veins long and curved. 


\section{ToMopelta MuNda, sp. nov.}

Reddish chestnut-brown, pubescent, punctate all over the upper surface and beneath upon the pectus. Head dull blackish; antennæ fuscous, sometimes piceous or fulvous at base, the apical joint whitish excepting at base, tips of all the joints generally whitish; rostrum fulvous, sometimes darker at base and tip. Pronotum rufo-castaneous on the front lobe, which is also less distinctly punctate than the other and has the lateral margin almost straight; the posterior lobe is dark brown, coarsely punctate, and has four short, yellow, longitudinal stripes; the humeral angles prominent, a little rounded, the transverse line separating the lobes deep, indented at the outer ends, and with a minute pit in the middle. Scutellum reddish brown, marked with a yellowish $\mathbf{Y}$ shaped figure, which is continued on the apical carina to the tip, the hollow space each side of tip dark brown. Beneath dark ferruginous, polished, especially on the venter. Legs pale yellow, hairy, punctate, a little brownish on the coxæ, base and tips of femora and tarsi. Hemelytra pale testaceous, minutely pubescent, remotely punctate with rufous or brown, middle of the costa with a small brown point; the inner apex of the corium has an irregular brown spot, which connects with the margin and runs out to a smaller spot on the extreme tip ; membrane clouded with brown, the outer border thick and pale; venter fulvous, or soiled yellow, feebly polished, the sutures blackish.

Length to tip of abdomen about 2 millim.; width of base of pronotum $\frac{3}{4}$ millim.

Several specimens of this bright little insect were captured by Mr. H. H. Smith while they were flying at sunset, in the forest, in April, at an altitude of 1000 feet above the sea. This insect bears some resemblance to the genus Drymus, Fieb., but it is much narrower than $D$. silvaticus, Fab., of Europe.

\section{Bathydema, gen. nov.}

Elliptical, body deep, thicker and wider than in Peritrechus, Fieb., minutely pubescent, dull, polished only on the venter. Head short, broad, inserted against the eyes, the eyes projecting a little beyond the side of the front of pronotum. Antennæ long, reaching almost to the tip of scutellum, the basal joint a little shorter than the head, the second longer, nearly equal to the third, the fourth much thicker, fusiform, about equal to the second in length; rostrum reaching between the anterior coxæ, not much thicker at base, the basal joint a little shorter than the throat. Pronotum trapeziform, thick, strongly sloping forwards, the lateral margin carinate through to the callous humeri; callosities prominent, long, placed obliquely ; stricture separating the lobes conspicuous only on the sides; surface punctate, dull. Underside of head, propleura and mesopleura coarsely punctate. Anterior femora moderately thick. Scutellum small, simple, a little longer than wide, longitudinally callous at tip. Corium dull, wide, minutely 
pubescent, with the veins thick and prominent, the costal margin almost straight, a little curved at tip ; membrane wide, with a large, closed cell at the inner angle from which two veins run curving towards the tip.

\section{Bathydema socta, sp. nov.}

Robust, blackish piceous, yellowish pubescent. Head tinged with brown, not polished, punctaice above and below; antennæ closely pubescent, pale fulvous or piceo-testaceous, with the basal joint darker above, and the thick apical joint fuscous, the apex of the second joint and base of the third sometimes with a narrow dark band; rostrum fulvo-testaceous, hairy, piceous at base and tip. Pronotum dull blackish, coarsely punctate, the anterior lobe interruptedly margined with yellow, the posterior lobe feebly sinuated behind, with a testaceous arc next the humeri and a dot of the same colour on the middle of the margin, the lateral margin pale castaneous behind; pleuræ dull piceous, punctate, pubescent, bordered with pale castaneous. Coxæ pale castaneous ; legs yellow, tinged with fulvous. Scutellum dull fuscous, transversely convex at base, obsoletely punctate, pubescent, compressed and testaceous at tip. Corium and clavus testaceous, crossed in common by a dark brown broad band at tip, which includes two short yellow streaks and a dot; membrane brownish, with a pale dot at tip. Venter dull piceous.

Length to tip of membrane 2 millim. ; width of base of pronotum $\frac{3}{4}$ millim.

This interesting little insect approaches nearer to Peritrechus, Fieb., than to any other genus with which I am acquainted. But the characters here given will, it seems to me, serve full well to separate it from that genus.

Four specimens were secured on the Soufrière volcano, in April, distributed in the moss, at altitudes of 2000 and 3000 feet above sea-level.

\section{SpHæRobius, gen. nov.}

Form similar to that of Herceus, Stål, but differs most conspicuously in having the anterior lobe of pronotum globose and as wide as the very short posterior lobe. The head is conico-ovoid, acute at tip, the tylus projecting prominently in front of the clypeus, with the two adjoining lobes of the cheeks short and feebly prominent; eyes placed on or below the line of the vertex; basal joint of rostrum thick and shorter than the throat. Antennæ moderately long, gradually thickening towards the tip, the basal joint much shorter than the head, the third joint a little shorter than the second, the apical joint longest and much thicker than the third; the bucculæ short and restricted to the tip. Collum of the pronotum wide below, narrow above; the anterior lobe of the pronotum fully as wide as the very short, transverse posterior lobe, separated by a deep stricture, coarsely punctate, with the posterior margin sinuated and the humeral angles callous. Anterior femora very thick, fusiform, 
armed beneath with about four long spines, which have shorter spines between them throughout the greater part of the length. Scutellum long, compressed and acute at tip. Wing-covers narrow, the costal margin almost straight, a little curved at tip ; veins of the corium distinctly prominent. Connexivum strongly elevated along the margin of the abdomen.

\section{Spharobius gracilis, sp. nov.}

Coal-black, polished beneath and on the anterior lobe of the pronotum, invested with erect hairs on most parts of the surface, both above and below. Head dull black, set with remote bristly hairs, remotely punctate, scabrous especially on the clypeus, the throat coarsely punctate; antennæ fulvo-piceous, with the apical joint and tips of the others fuscous ; rostrum piceous, paler on the middle, reaching between the anterior coxæ. Pronotum jet-black, with the posterior lobe rufo-piceous, coarsely and evenly punctate, pubescent, the anterior lobe set with bristly hairs, obsoletely punctate in remote lines, a few series of more distinct punctures upon the lower part of the sides. Legs piceous black, paler on the tibiæ, the tarsi chiefly testaceous, the anterior tibia of the left side (possibly of both sides) armed with a long curved spine. Scutellum pubescent, coarsely, remotely punctate, paler at tip. Corium whitish testaceous, coarsely punctate with brown in longitudinal series, the posterior half blackish brown, with a subquadrate pale spot exteriorly before the tip, the base also brown; membrane short, incomplete, blackish, pale at base: Abdomen black, polished.

Length to tip of venter $4 \frac{1}{2}$ millim.; width of base of pronotum 1 millim.

One specimen only was captured, on the leeward side of the island. As it is closely glued to the slip of card the underside and femora of the right side cannot be studied.

The presence of the spur on the anterior femur adds a new element of structure to this remarkable insect. It bears much resemblance to an ant, and is much narrower than the other species described as Herceus insignis, Uhler.

\section{Fam. CA P S I D}

\section{CyLloceps, gen. nov.}

Long elliptical, blunt at both extremities, almost flat above, polished, with the hemelytra thin, pellucid. Head very short, vertical, the sides enclosed by the vertical eyes ; tylus very short, projecting a little before the line of the eyes; vertex transverse, cylindrico-convex on the middle, scarcely higher than the low-placed upper line of the eyes; bucculæ wide apart, narrow; rostrum slender, the basal joint longer than the head; gula constricted; lobe behind the eye in contact with the pronotum. Pronotum transverse, trapezoidal, feebly sloping, almost flat, destitute of a collum, the sides oblique, bordered with a linear callous margin

Proc. Zool. Soc.-1893, No. XLVIII. 
from the humeri to near the bluntly rounded anterior angle; the surface polished, with the callosities large, smooth, almost contiguous, the suture behind them faintly defined, the humeri acutely tubercular, the anterior margin slightly excavated across to the middle of the eyes, and the posterior margin feebly sinuated. Scutellum of medium size, about as wide as long, prominently convex. Legs of medium size, the posterior femora long, curved, compressed; unguiculi long, slender, widely spreading apart. Hemelytra complete, much longer than the abdomen, bluntly rounded at tip, almost parallel-sided, the costal margin only a little curved, abruptly reflexed, the discoidal vein well defined, and the membrane almost as long as the corium. Abdomen ample, not contracted at base, blunt at tip in the female, but tapering towards tip in the male.

\section{Crlloceps pellicia, sp. nov.}

Pale testaceous, long elliptical, polished, minutely pubescent. Head yellow, black along the middle line, including the tylus, sometimes with a black band between the lower line of the eyes; bucculæ blackish; rostrum yellowish, piceous at tip, reaching behind the middle coxæ. Antennæ long, gradually decreasing towards the tip, the basal and second joints stout, the second much the longest, obscure yellowish, the third a little shorter than the second, and the fourth still shorter, the basal one shortest, a little longer than the head, black excepting at base and tip. Pronotum moderately polished, dull yellow, obscured by brown posteriorly and towards the sides, the surface a little scabrous, transversely wrinkled, remotely punctate, minutely pubescent, the sides beneath more or less infuscated and a little scabrous; sternal segments polished, mostly yellow, those of the mesosternum more or less dusky. Coxæ and legs pale yellow, the femora usually a little darker at base and with the immediate tip piceous, the nails and tip of tarsi piceous. Scutellum dark brown, obsoletely carinate on the middle line, polished, not distinctly punctate. Hemelytra pellicular, translucent, pale testaceous, obsoletely fuscous on the inner border of the clavus and corium, the coarse bounding vein at basal angle of membrane piceous, the vein on middle of corium is also dusky in some specimens; veins of membrane usually a little brownish. Venter yellow, more or less dusky on the middle, with the sides tinged with rufous or orange and the ovipositor piceous.

Length to end of venter $2 \frac{1}{2}$ millim., to tip of membrane 3 millim.; width of base of pronotum barely 1 millim.

Several specimens of both sexes, collected by Dr. Gundlach in Cuba, were submitted to me for examination, and others are in the collection from the island of St. Vincent, which were captured by Mr. Herbert H. Smith in the month of May. I have also seen a specimen from Southern Florida and others from the island of San Domingo.

Not having specimens for dissection, I have been unable to ascertain a few points necessary to establish the precise relations 
of this genus. It seems to be closely related to Agalliastes, but it is without the saltatorial hind femora, and it differs from that genus in the details given above. In a few specimens the pronotum has simply a narrow black band across the base.

\section{Genus Melinna, Uhler.}

\section{Melinna Minuta, sp. nov.}

Narrower than usual, with the sides parallel, the surface highly polished, dull dark horn-brown, relieved with pale yellowish testaceous. Head particularly convex, very highly polished, with a few obsolete punctures on the crown, dull pale yellowish, with the middle broadly piceous and the tylus dusky; the occiput contracted, narrower than the collum of the pronotum, but the space between the eyes wider than the front of the pronotum; eyes brown, large, most prominent laterally, almost spherical. Antennæ moderately stout, horn-brown, the second joint pale at base, reaching from the front of eye to basal angle of pronotum, becoming gradually a little thicker towards the outer end, the third joint abruptly thinner and with the fourth continuing of the same thickness throughout; both of these joints pale yellow, hairy; rostrum slender, yellowish white, reaching behind the anterior coxæ. Pronotum transverse, moderately convex, obsoletely punctate, with the lateral margins very oblique, a little sinuated, with the edge moderately acute, but not carinated, and the humeral angles prominent, the posterior margin hardly sinuated, the border a little rolled and turned down. Scutellum minutely, obsoletely punctate, concolorous with the thorax and hemelytra, and polished like them, convex, pinched at the tip. Legs, coxæ, and ovipositor ivory-white. Hemelytra polished like the pronotum, minutely golden pubescent, minutely obsoletely punctate; the costal border straight, honey-yellow; the incisure of the cuneus and inner edge of the same pale; membrane a little dusky, darker at base. Venter chestnut-brown, polished, a little paler at tip.

Length to tip of venter $1 \frac{3}{4}-2$ millim.; width of pronotum $\frac{7}{8}$ of a millim.

Similar to $M$. elongata, Uhl., but with a nick behind the eyes. Two specimens are present in the collection and a fragment of a third adheres to the card of another pin. Two specimens were obtained in the wooded country at an altitude of 1000 feet above sea-level, and a third was beaten from bushes in the Petit Bordelle Valley at an altitude of 1600 feet above the sea.

Another small species, coarsely punctate, apparently belonging to this same genus, was obtained, but the only specimen present is too imperfect for description.

\section{Genus LyGUs, auctor.}

\section{LyGUS obtusus, sp. nov.}

Soiled pale green, polished, minutely pubescent, with the head short and blunt as seen from above and closely pressed against the 
pronotum, with the eyes large and prominent outwards; the face triangular, convex on middle, highly polished, obsoletely punctate, with a punctate impressed line on the middle of the vertex; tylus prominent, a little discoloured, with the cheeks each side callously prominent ; antennæ moderately long, the second joint rod-shaped, as long as the width of the pronotum, third and fourth more slender, tinged with fuscous; rostrum pale greenish, reaching upon the middle coxæ. Pronotum short, strongly convex, minutely pubescent, highly polished, unevenly punctate in wavy transverse series, the posterior margin feebly sinuated, the lateral part of this margin widely rounded, with the edge acute and pale, terminating exteriorly in an acute tubercle ; pleura with a dark stripe extending to the end of the posterior segment; legs pale green, a little obscured at end of femora, the posterior femora with the common oblique pair of brown bands near the tip; tibial spine fuscous. Beneath whitish. Hemelytra closely pale pubescent, unevenly punctate, with the disk infuscated, the outer border broadly pale and the cuneus equally pale, the apical extremity of the inner border of corium pale piceous, the clavus coarsely punctate like the convex scutellum; the membrane brown, especially at base.

Length to tip of venter $3-3 \frac{1}{4}$ millim.; width of pronotum $1 \frac{1}{2}$ millim.

Two specimens, a male and a female, were obtained on the leeward side of the island.

The scutellum may be faintly pale along the middle line and a little obscured each side near the tip.

\section{Genus Fundanius, Dist.}

Fundanius Rubens, sp. nov.

Cinnabar-rufous, tinged with orange. Form normal, the upper surface roughly punctate, excepting the head. The head highly polished, less distinctly punctate, with the face vertical, deeply sunken and grooved on the middle; the eyes prominent, dark brown. Antennæ brownish black, stout, stouter in the male; third joint short, abruptly slender; the fourth a little shorter and more slender than the third; the second joint rod-shaped, not tapering, a little shorter than the width of the pronotum. Rostrum slender, yellow, reaching between the middle coxæ. Pronotum strongly, broadly constricted behind the hood of anterior lobe, most coarsely punctate on the posterior lobe, and the disk occupied behind by a large trapezoidal black spot which touches the posterior margin, anterior part of the middle line carinated; propleura and sternum bright orange, the meso- and metapleuræ soiled orange or pale brown, but brighter on the sternum. Legs and coxæ pale dull testaceous, soiled brownish on the apices of femora and tibiæ, the tarsi and nails piceous. Scutellum blackish brown, coarsely punctate, deeply sunken and grooved on the middle line, the margin prominently elevated, callous, smooth. Hemelytra black along the entire length including the membrane, the outer border broadly 
orange, and this colour covers the entire cuneus, the outer border and cuneus less coarsely punctate than the clavus. Venter blackish, with the disk basally dull orange.

Length to end of venter $2 \frac{3}{4}-3$ millim., to tip of membrane 4-4 $\frac{1}{2}$ millim.; width of pronotum $1 \frac{1}{4}-1 \frac{1}{2}$ millim.

Three mature specimens, a male and two females, and two larvæ were secured. These were met with on both sides of the island, and the larvæ were obtained at the roots of grass on the marsh 500 feet above the level of the sea.

This genus belongs to the division Clivinemaria of Reuter, and this species, together with the two other hooded species of Mr. Distant, may eventually be found to belong to the genus Clivinema, Reuter. In this genus there is lack of uniformity in the proportions of the antennæ, not only in the two sexes, but also among individuals of the same species.

\section{Genus Pecilosoytus, Fieber.}

\section{Pecilosoytus obscurus, sp. nov.}

Closely related to $P$. basalis, Reuter. Dark chestnut-brown, oblong-ovate, spread with close fine golden pubescence; female broader than the male. Head long, acutely triangular, dull, not distinctly punctate, polished when denuded; face convex, surface around the eyes, a slender streak on the middle, and the cheeks each side of tylus more or less yellowish; the tylus, bucculæ, and base, tip, and middle of rostrum dark brown, the rostrum mostly yellowish and reaching behind the posterior coxæ; the transverse carina at base of head prominent, piceous, polished. Antennæ of medium thickness, as long as from front of eye to tip of cuneus; the joints either dark brown or pale with brown ends, excepting the apical ones which are pale fuscous and nearly setaceous; the second joint is about as long as the base of pronotum. The pronotum is moderately convex, obsoletely punctate, and covered with the same prostrate golden pubescence as the head, scutellum, and hemelytra; the collum is generally testaceous or white, and back of its middle is a short yellow double spot or band, against each anterior angle there is usually a velvet-black round spot, the posterior margin is a little sinuated and usually pale; the sternum, posterior border of pleural segments, and coxæ are usually pale testaceous. Legs dark brown in full-coloured specimens, but pale yellowish brown in others, paler on the tibiæ, and having the posterior femora marked near the tip by the usual two darker bands. Scutellum moderately convex, obsoletely wrinkled and punctate, bordered with testaceous near the tip. Corium, clavus, and cuneus finely but distinctly punctate, the embolium and costa with a testaceous spot at base, the fracture and tip of cuneus and vein of membrane dull testaceous; the membrane dark fuliginous. Venter black-piceous or sometimes pale chestnut-brown on the middle, spread with silvery pubescence and with the edge of the genital valves testaceous. 
Length to end of venter $2 \frac{1}{2}$ millim., to tip of membrane $2 \frac{3}{4}-3$ millim.; width of base of pronotum $\frac{7}{8}-1 \frac{1}{4}$ millim.

Numerous specimens, including some of both sexes, were collected in various parts of the island. This species is also common in Cuba, and I have swept specimens of it from weeds in the department of the Grand Anse, Hayti. Other specimens have also been seen by me, which were collected in Southern Florida, Mexico, Jamaica, and Brazil. This form will illustrate the variation which occurs in the joints of the antennæ, some specimens having the antennæ tapering, while in others the apical joints are abruptly setaceous.

\section{Fam. TINGITID T.}

\section{Trponotus, gen. nov.}

Form similar to Gargaphia, Stål, but lacking the transverse carina at the end of the mesosternum. The pronotal hood protracted long in front of the head, acutely compressed at tip and curved downwards, opaque, carinate on the middle line, with two longitudinal series of sunken areoles, followed beneath at base by a shorter series of smaller ones, with the lower border strongly reflexed. Carina of the mesonotum high, indistinctly areolate, arched and sinuated. Wing-covers almost flat, subquadrangular, narrowing posteriorly, the costal area ampliated about the middle, with the border strongly reflexed; the basal division of the area is occupied by two imperfect series of areoles, which are followed towards the tip by a single series of much larger ones. Sternal carinæ high, set wide apart, and curving on the metasternum. Throat enclosed by an elevated border of the prostethium. The antennæ slender, of medium length, with the apical joint short, clavate. Pronotal lobes subtriangular, widely extended, protracted in a narrow lobe anteriorly, reflexed, set with curving series of nearly circular, large areoles. Legs slender.

\section{TYPONOTUS PLANARIS, sp. nov.}

Oblong, milk-white, opaque, contracted at the base of wingcovers and narrowing obliquely behind the middle, marked with brown across the sunken middle of the pronotum and in the grooves each side of the hood. Hood long and narrow, acutely compressed at tip. Scutellum with an obscure spot each side. Veins of the wing-covers a little dusky in patches, sometimes tinged with yellow, the discoidal area with a dusky spot at base and tip, the costal area usually with a brown crescent near the base and one or two spots near the tip; veins of the membrane marked with fuscous so as to form a broad, double, transverse loop next the tip : this dark area encloses cells of a larger size and more transparent colour than those of the corium. Underside black, with the bucculæ, margins of the pleural pieces, and sternal carinæ whitish. Legs pale fulvous, darker at the ends of femora, tibiæ, and tarsi, Antennæ pale, the clavate apical joint dusky. 
Length to end of abdomen 1- $\frac{1}{8}$ millim., to tip of wing-covers 3 millim.; width across lobes of pronotum 2 millim.

The less mature individuals of this species are paler and almost translucent in the meshes of the wing-covers, while the fully mature ones are tinged with yellow and more opaque.

About one dozen specimens were collected by Mr. Herbert H. Smith.

\section{Genus Corythuca, Stål.}

Examples of a species of this genus, approaching C. gossypii, Fabr., were taken on the island by Mr. Smith, but the few specimens are either immature or not in condition for accurate identification.

\section{Fam. EMES I D . \\ Genus Evresa, Fabr.}

Emesa angulata, sp. nov.

Body and members more robust than in E. longipes, De G., and the other normal species. Obscure fulvo-testaceous, unpolished, with the sides of the head and thorax broadly blackish piceous. Head stout and deep, remotely punctate in patches, obsoletely scabrous, minutely pubescent, the division behind the stricture longer than the one before it, base of tylus armed with a short curved spur. Rostrum reaching the anterior coxæ, the basal joint stout; the second a little longer and thicker, tapering towards the tip; the third pale testaceous, tapering at base, swollen, growing quite slender, longer than the first and second united. Antennæ slender, filiform, of medium length, fuscous, pale at base, and sometimes with an obscure band on this paler portion, the basal joint equal to the thorax in length, the second much shorter. Middle and posterior legs filiform; the tibiæ more slender than the femora, black at base and banded with black, in four spots upon the femora and three upon the tibiæ; anterior femora thick, subcylindric, compressed, obscurely banded with fuscous, set with two sizes of teeth from before the middle to the tip, the inner tooth much longer than the others; the tibiæ fuscous with a pale band, the tarsal nail not quite reaching to the inner tooth. Pronotum obsoletely scabrous and almost flat above, faintly marked with a longitudinal impressed line, the anterior half a little swollen, back of this the lobe is a little contracted, while the posterior lobe is quite small, and elevated into two transverse toothed callosities, anterior angles tubercular. Mesonotum taperingly contracted from the middle forwards, so as to be much narrower than the pronotum, while the basal portion swells to nearly the width of the pronotum, the middle line has a slender carina which runs back through the grooved metanotum; the metanotum is much shorter than the mesonotum and has carinated sides. The underside, including the venter, is smooth, somewhat glossy on the sternum, with the venter dusky and dull. The abdomen is thick and gradually widens posteriorly, the posterior end being obliquely truncated in the female, but 
rounded and with a curved spur above in the male; the outer angle of the dorsal segments is more or less toothed.

Length to end of abdomen 18-19 millim.; width of front of pronotum 1 millim.; width of last segment of abdomen $1 \frac{1}{4}-1 \frac{1}{2}$ millim.

Several specimens of both sexes were secured at various places on the island. Only unwinged ones were found, and three or four of these are in the younger stages. These nymphs are essentially like the adult and differ more in size than in the elements of structure. The form of pronotum and abdomen with the accompanying teeth is nearly the same as in the full-grown specimens. One specimen was found on the leeward side of the island, in September, at an altitude of 2000 feet, and others were captured under logs on the Richmond estate, leeward, in an open valley near sea-level, on October 31 . In my collection there are specimens from the vicinity of Panama.

\section{Emesorsis, gen. nov.}

Form similar to that of Ploiaria, Scop., agreeing therewith especially in the form of the head, but differing in the venation of the hemelytra. Head wide and short, tumidly convex behind, the transverse stricture crossing between the eyes; the throat unarmed. Rostrum reaching between the anterior coxæ; the basal joint stout, extending behind the line of the eyes; the second shorter, tumid; the third slender throughout, shorter than the basal one. Antennæ almost setaceous, the basal joint a little stouter, about as long as the head and pronotum united; the second and third shorter, subequal. The eyes subglobular, placed below the level of the vertex. Anterior tibiæ and tarsi together scarcely shorter than the femora, the femora apparently armed with fine spines throughout nearly the entire length. Pronotum short, the posterior lobe more than twice as long as the anterior one, tumidly convex behind ; the anterior lobe very short, elevated into a callosity each side. Scutellum small, distinct, conical at base, constricted behind, the narrowed portion evenly cylindrical to the tip. Hemelytra membranous throughout, gradually widening towards the tip, the costal margin straight to beyond the middle; veins of the corium sharply distinct, the transverse ones few, crossing at nearly right angles, the cells growing larger posteriorly, the apex with a triangular narrow cell at both the outer and inner angle; cells of the membrane large, the basal one longest, ending in a protracted narrow loop, which sends off a vein to the tip. Abdomen moderately flat, widened towards the middle.

Emesopsis nUbiuus, sp. nov.

Pale fulvo-testaceous, elongate, but not linear, smooth above, pilose over most of the surface. Head obsoletely, minutely punctate, the transverse impressed line and a small spot on the middle brown. Antennæ setaceous, the last joint infuscated; eyes fuscous. Legs pilose, the intermediate and posterior femora 
banded with pale fuscous, the anterior legs a little clouded with fuscous. Pronotum smooth, obsoletely, minutely punctate on the posterior lobe. Hemelytra longer than the abdomen, the veins and a series of spots at the apex of the membrane fuscous. Outer margin of the abdomen piceous.

Length to end of abdomen 4 millim., to tip of membrane $4 \frac{3}{4}$ millim.; width of base of pronotum $\frac{3}{4}$ millim.

One specimen is in the collection from this island.

This species seems to be not rare in Cuba. Several specimens have been sent to me from that island by Dr. Gundlach, and others are in his collection.

Fam. VELIID E.

Genus Microvelia, Westw.

\section{Microvelia marginata, sp. nov.}

Dull black, nearly wedge-shaped, minutely pubescent, and obsoletely punctate, with the breast orange and the pronotum bordered with orange. Head rather blunt, convex between the eyes, a little compressed and produced at the end of the clypeus, the underside pale testaceous. Antennæ stout, closely hairy, black ; third and fourth joints longer than the others, the fourth longest, acutely tapering at tip ; the basal joint thicker than the others, much longer than the second, pale beneath. Rostrum stout and swollen at base, reaching behind the anterior coxæ, pale testaceous, piceous at tip. Pronotum broad, moderately convex, with the humeral angles bluntly ronnded, and not prominent as in $M$. capitata, Guér. Pectus broadly yellow, dusky on the middle and posteriorly. Coxæ and legs pale testaceous; the posterior legs dusky above, and fulvous on the middle of the tibiæ. Scutellum dusky, mostly concealed by the pronotum. Wing-covers black, bluntly rounded at tip. Abdomen black above, tinged with lead-colour and a little sericeous beneath, the lateral margins broadly fulvous; the venter has sometimes a row of fulvous dots ach side.

Length to tip of abdomen $1 \frac{3}{4}-2$ millim., to end of wing-covers $2 \frac{1}{4}$ millim.; width of pronotum $\frac{3}{4}$ millim.

Several specimens, both winged and unwinged, were collected by $\mathrm{Mr}$. Smith in the pools of cool water at various localities on the island.

\section{Observations on the Refraction and Vision of the Seal's} Eye. By G. Lindsay Johnson, M.D., F.Z.S.

[Received November 21, 1893.]

In the course of my investigations on the vision of the Mammalia, I was particularly struck with certain peculiarities in the eye of Phoca vitulina, the Scotch Seal, so frequently met with off our northern coasts. The eye, as everyone must haye observed, is 
particularly large for the size of the animal, being slightly larger than our own. The sclerotic is chalky white, almost entirely free from blood-vessels, and the cornea very large, round, and of great convexity. This latter point is very remarkable for a reason which I will point to later on.

The iris is of a rich yellow-brown colour and contracts rapidly to light. The eye is capable of being partly retracted into the orbit and is protected by a well-developed membrana nictitans. I have repeatedly amused myself by making experiments to ascertain how far the m. nictitans can be drawn over the eye of the Seal, but I could never get it to extend over more than a third of the distance across the cornea of its own accord, although I have tried, by pinching the conjunctiva or by placing hairs and other foreign bodies on the cornea, to stimulate it to further action; but this always failed to have any effect, as, contrary to what we find in most text-books, the membrana nictitans is never used for brushing away foreign bodies as in birds ${ }^{1}$. I hope in a future paper to discuss the action and purpose of the membrana nictitans in various families of the Mammalia, but space compels me to confine myself in this paper to the apparatus more immediately concerned in vision.

Before going further I will, with your permission, pass a few remarks on the nature of vision in ourselves. The human eye, as we are all aware, is a nearly spherical expansion of the optic nerve and its connective-tissue coverings. The posterior half is lined with the light-sensitive retina, while the anterior portion, together with the contents of the globe, form a dioptric apparatus for the convergence of rays on its surface. This dioptric system is made up of four distinct media : the cornea, the aqueous humour, the lens, and the vitreous body. This optical system consists then of the transparent media and the refracting surfaces which separate them from the air and from each other. Now if we examine their refractive indices, we shall find that, excepting the lens, all the media have the same refractive index, viz. 1.3365. But this is the refractive index of sea-water, so that if we plunge our heads under the waves our dioptric apparatus becomes at once simplified down to a single lens in front of a sensitive surface (the retina). We shall thus, under water, be quite unable to see anything around us distinctly, and that for a very simple reason. We know that in a state of rest parallel rays come to a focus on the retina of a normal eye. Now in a state of rest the crystalline lens has in aqueous humour (or, what amounts to the same thing, in sea-water) a mean focal distance of $50.61 \mathrm{~mm} .=1.994$ inches. Since the distance between the optical centre of the lens and the retina amounts to $15.62 \mathrm{~mm}$., it is clear the image for parallel rays must lie $50 \cdot 61 \mathrm{~mm} .-15 \cdot 6 \mathrm{~mm}$., or $35 \mathrm{~mm}$., behind the retina ; in other words, we need the addition of a convex lens of something

1 Exceptions to this rule occur in the Ungulata and certain other grass-
feeding animals. 
like $1 \frac{1}{2}$ in. focus in air to see with under water. But this cannot be made of glass, since the latter has nearly the same refractive index as water. To meet this difficulty Dr. Dudgeon some years ago had a pair of spectacles made consisting of portions of two hemispheres of plain glass with parallel surfaces, mounted in a brass ring with their convex surfaces nearly touching one another. . I have brought the original pair to show you. In air they produce no effect, neither magnifying nor reducing; but in water the biconcave air-lens, for such it is, becomes a biconvex one, the convex surfaces of the water in this case forming the lens. Dr. Dudgeon, who has the credit of entirely solving this problem, made a number of sketches under water, one of which I have reproduced. Were it not for the distortion and astigmatism everything could be seen; even the date on a coin can be made out.

Fig. 1.

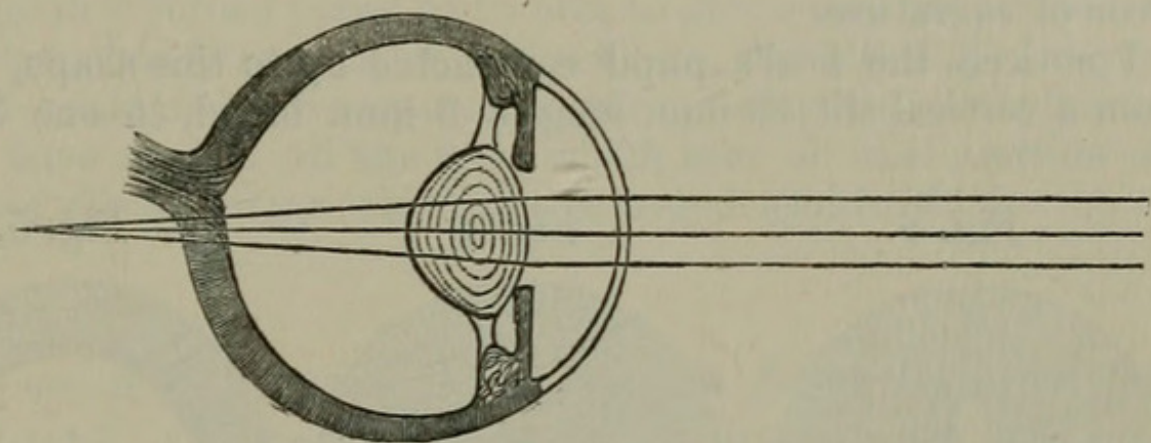

Fig. 2.

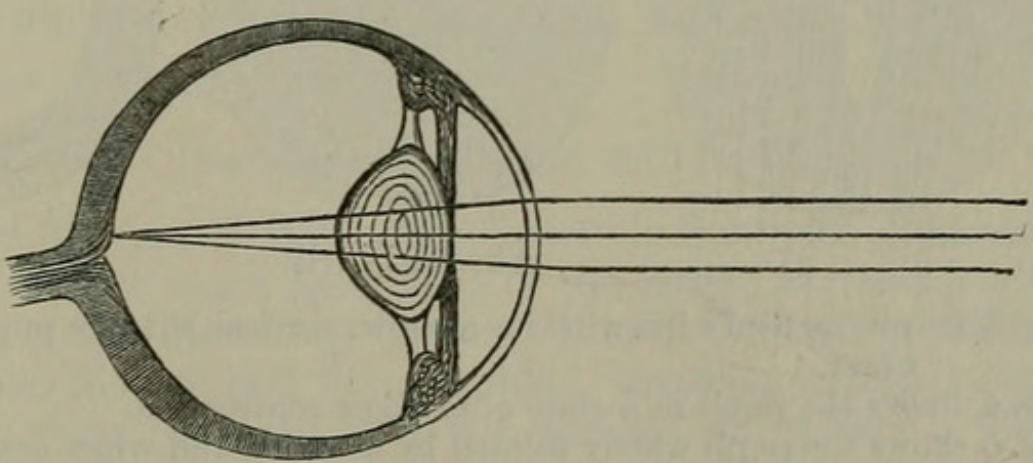

Transverse section of the Seal's eye; natural size. (Diagrammatic.)

Fig. 1 shows the path of light-rays in the eye when uncorrected under water. Fig. 2 shows the path of rays when the eye is corrected for air.

In the Seal's case the problem is rather more complicated, for the Seal has to see under four conditions. He has to see out of water when out of water, in water when under water, out of water when under the water, and in water when out of the water. The first two conditions alone need be considered, as the two latter follow by necessity.

Now the Seal's eye is very much the same shape as our own, excepting that the cornea is larger and more convex and the anterior chamber very deep. This convexity of the cornea is very curious, as one would expect to find it nearly flat as in the fishsince the flatter the cornea and the nearer the lens to it, the less 
would be the thickness of the media to be neutralized by the water. In most fishes' eyes (as we are aware) the lens almost touches the cornea and is nearly spherical.

On taking the refraction of the living Seal's eye out of water, I was surprised to find that he possessed a myopia of 4 diopters or 10 in. in the vertical meridian and 13 diopters or about 3 in. in the horizontal,- - the difference between these two curvatures producing an astigmatism of $9 \mathrm{D}$, an amount altogether incompatible with even useful sight and rarely if ever met with among human beings even in disease.

On applying a solution of atropine to the eye, I had an opportunity of ascertaining how the iris overcame this error. It is well known to oculists that high grades of astigmatism may be almost entirely neutralized by an opaque diaphragm in the centre of which is a narrow stenopaic slit placed at right angles to the error of curvature.

I noticed the Seal's pupil contracted up to this shape, varying from a vertical slit $13 \mathrm{~mm}$. long by $3 \mathrm{~mm}$. broad, to one $3 \frac{1}{2} \mathrm{~mm}$.

Fig. 3.

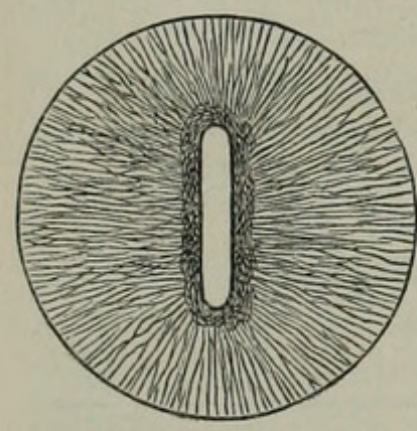

Fig. 4.

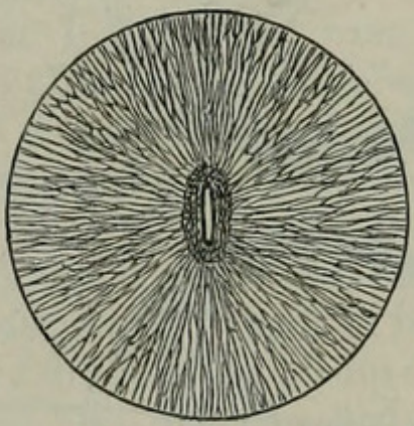

The Seal's iris.
Fig. 5.

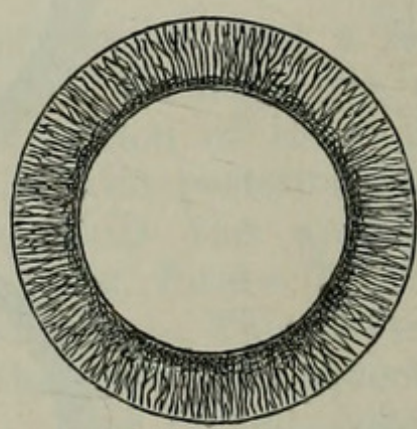

Fig. 3 shows the Seal's iris with its narrow, vertical slit-like pupil as seen out of water.

Fig. 4 shows the pupil in a state of extreme contraction.

Fig. 5 shows the pupil widely dilated by atropine and when under water.

long and barely $1 \mathrm{~mm}$. broad. By careful estimation of the refraction in the two opposite meridians by the direct method with the ophthalmoscope and by retinoscopy, I ascertained both eyes to have the same refraction in the two meridians and the meridian of greater myopia to be the horizontal, which could be corrected by a stenopaic slit in the vertical meridian.

How does this extraordinary amount of astigmatism help the animal to see? The difference between vision in air and in water, viz. $26 \mathrm{D}$ or $27 \mathrm{D}$, may be corrected to a large extent by powerful accommodation, and the $13 \mathrm{D}$ of myopia may correct half the amount of error in the horizontal meridian. On the other hand, the vertical meridian will only be corrected to the extent of $4 \mathrm{D}$, which is only a sixth or a seventh of the total.

Moreover, I find that the Seal's iris dilates to the full in water 
and closes more or less in air, because the correction for the astigmatism is evidently made for air and not for water. Now our iris dilates when the accommodation is relaxed, and contracts when it is called into play; and if in the Seal the accommodating mechanism be the same as ours, the above-mentioned changes would obviously only make matters worse.

But here again the question is beset with difficulties, for this myopia could only be of service if it were due to the lens, since any curvatures of the cornea would be neutralized by the water.

At present my observations go to prove that the iris is to some extent at least under the control of the animal's will, since in one Seal, at any rate, I observed the pupil moving out of all proportion to the accommodation, while, on the other hand, I induced accommodation by approaching a piece of fish without any alteration in the pupil.

I hope in a future paper to be able to give some explanation for this extraordinary amount of astigmatism, and although I have a theory I would rather reserve any further attempts at an explanation until I have verified all the facts which bear on the question and examined all objections which can be urged against it.

4. On some Specimens of Mammals from Lake Mweru, British Central Africa, transmitted by Vice-Consul Alfred Sharpe. By P. L. Sclater, M.A., Ph.D., F.R.S., Secretary to the Society.

\section{[Received November 16, 1893.]}

Mr. Alfred Sharpe, H.B.M. Vice-Consul in Southern Nyasaland, has kindly sent me some specimens of the larger Mammals which he obtained during his recent journey from the north end of Lake Nyasa to Lake Mweru and the Luapula ${ }^{1}$, together with a number of flat native skins procured from the natives at Mweru. These I have now the pleasure of exhibiting.

In a letter written from Blantyre (28th March, 1893) after his return, Mr. Sharpe gives the following interesting account of the animals met with on his route :-

"On the road from Nyasa to Tanganyika almost no game is seen until the Saisi is reached [this river, rising in the Mambwe Country, flows N.E. and E. to Lake Hikwa]. There, for the first time on this route from the sea to Tanganyika, one finds the Cobus vardoni, also the Impala (Aipyceros melampus), Roan Antelope (Hippotragus equinus), Lichtenstein's Hartebeest (Bubalis lichtensteini), Eland, Zebra, \&c. After leaving the Saisi flats little game is seen on the road thence to the south end of Tanganyika.

"I doubt if game can, anywhere in Central Africa, be more

${ }^{1}$ See Mr. Sharpe's paper on this subject, Geogr. Journ. i. p. 524(1893), and the accompanying map. 
plentiful than in the Mweru and Luapula Countries, though there may be districts which have a greater variety. Cobus vardoni and C. lechee run in enormous herds. Buffaloes and Zebras are also there in vast quantities. The two first-named Antelopes are frequently found together, are much alike in appearance, and are both known by the natives as 'Nswala.' (The Impala is also called 'Nswala' by them.) The horns of the Letchwé have a much larger spread than those of Vardon's Antelope, but at a distance it is difficult to distinguish between the two. The Letchwé has a little black stripe on the fore legs which is not found in Vardon's Antelope. A noticeable feature about the male Letchwé is that when he runs he puts his head down, laying back the horns. Vardon's Antelope does not do this.

"Near the north-east end of Lake Mweru I met with a species of Waterbuck quite different from those inhabiting Nyasaland. The whole skin is of a darker- " bluer"-colour. The white marks on the buttocks are not so distinct, and the beast is somewhat smaller in size than that Antelope. I forward you, through Mr. H. H. Johnston, a skin of one of these Mweru Waterbucks, which was shot by Mr. John Kydd (who accompanied me on my journey). Mr. Crawshay has obtained several of them. I also forward you skins and horns of the Cobus vardoni and C. lechee; also the horns of male and female Roan Antelope, and a quantity of skins of small mammals, monkeys, cats, \&c., all from Mweru.

"One skin which I send is of a diminutive little Antelope from Mweru. I never saw it alive myself, but bought the skin from a native, who told me that it has very small, short, straight horns. My ' boys' from Nyasaland do not know it.

"The "Situtunga'" frequents the Great Mweru Marsh, and many of the swamps north, east, and south of Mweru Lake. Mr. Crawshay saw one, and obtained the horns of two, but neither he nor I succeeded in shooting a specimen; they live almost in the water.

"The African Cattle-plague has created terrible havoc among the wild game on the Lower Luapula (near its entrance into Lake Mweru); also, to a less degree, in Itawa, Ulungu, and Unyamwanga. All the dying beasts that I saw had a more or less copious discharge from the nose. Buffalo, Vardon's Antelope, and the Letchwé seem to have suffered most.

" Around Lake Mweru, both the 'Njiri' (Wart-hog) and the 'Guruvi' (which, if I am not mistaken, is one of the River-hogs), are very plentiful. I send you heads of each, with the tusks in; you will see how different they are.

"On the southern shores of Lake Mweru Lions are more plentiful than I have seen them elsewhere in British Central Africa, and I had some lively times with some of them. I am able to confirm the fact that Lions do occasionally climb trees. I saw one, on one occasion, high up in a large bushy tree, he was more than fifteen feet from the ground. On seeing us, he came down to the ground,

${ }_{1}$ Tragelaphus spekii, I believe.-P.L. S. 
crashing through the branches, having (I think) lost his hold and fallen. I shot him as he bounded off. He was a male, threequarters grown. The trunk of the tree was rather sloping and not difficult to climb.

"The extensive marshes through which the Luapula runs immediately before entering the south end of Mweru are the refuge of many Elephants, and this is one of the few spots in the southern portion of Equatorial Africa where they are still plentiful. The cattle-plague has not touched them.

"Rhinoceroses (of the Black species) are scarce throughout the Mweru and Luapula Countries. I saw none on my last journey, and only once came across their spoor. Buffalo and Burchell's Zebra are to be seen in vast herds in the country east of Mweru Lake, on the borders of the Great Mweru Swamp. I have seen them in herds of many hundreds. Throughout Itawa, Zebras are constantly met with.

"Buffaloes are numerous on the banks of the Luapula; Roan Antelopes throughout the country from Tanganyika west and south. Reedbucks and Bushbucks are found everywhere. Elands, Sable Antelopes, and Hartebeests are also seen throughout the countries that I have mentioned, but are not so plentiful."

I now proceed to give a list of the species represented in Mr. Sharpe's collection, so far as I can distinguish them. To make the list of the Mammals of this district as complete as possible I have added the names of some species represented in a series of skins and horns from Lake Mweru transmitted home by Mr. R. Crawshay (who was lately Resident at the Station called Rhodesia, at the N.E. corner of Lake Mweru) along with Mr. Johnston's collections.

\section{Cercopithecus opisthostictus, sp. nov.}

Two flat skins, which appear to have been used as dresses. So far as I can tell, they belong to a Cercopithecus allied to C. samango (see above, p. 251), but distinguished by the blackish under surface, the black upper back, and the two small rufous patches on each side of the tail. The species may be diagnosed as follows :-

Supra pallide cinereo et nigro confertim annellatus, capite obscuriore; cervice postica, humeris cum manibus et pedibus extus et cauda (nisi ad basin) nigris; plaga parva ad latus dorsi postici utrinque castanea: subtus nigrescens. Long. corp. 24 poll., caudce 25 poll.

Hab. Africa Centr. Britann. ad Lacum Mweru.

2. Felis servad, Erxl.; Elliot, Mon. Fel. pl. xxvi.

One flat skin, apparently of this Cat, or of a nearly allied species.

3. Felis Caffra, Desm.; Elliot, Mon. pl. xxxi.

One flat skin of a Cat of this group, which is widely spread over Africa. 


\section{$2 \mathrm{BHL}$ Biodiversity Heritage Library}

Flower, William Henry. 1893. "November 21, 1893." Proceedings of the Zoological Society of London 1893, 691-729.

https://doi.org/10.1111/j.1469-7998.1893.tb00568.x.

View This Item Online: $\underline{\text { https://www.biodiversitylibrary.org/item/97156 }}$

DOI: https://doi.org/10.1111/j.1469-7998.1893.tb00568.x

Permalink: https://www.biodiversitylibrary.org/partpdf/72816

\section{Holding Institution}

Natural History Museum Library, London

\section{Sponsored by}

Natural History Museum Library, London

\section{Copyright \& Reuse}

Copyright Status: Public domain. The BHL considers that this work is no longer under copyright protection.

This document was created from content at the Biodiversity Heritage Library, the world's largest open access digital library for biodiversity literature and archives. Visit BHL at https://www.biodiversitylibrary.org. 